\title{
Zemřel nestor české tibetanistiky Josef Kolmaš (1933-2021)
}

\author{
DANIEL BEROUNSKÝ \\ Přeložila Jana Valtrová*
}

Josef Kolmaš, jeden z úzkého okruhu zakladatelů moderní tibetanistiky, zemřel 9. února 2021 ve věku 87 let. Mezinárodní vědecké komunitě je znám jako autor řady prací na téma čínsko-tibetských vztahů, českému čtenáři je patrně známější jako překladatel mnohých knih o Tibetu, Číně a Indii.

Josefa Kolmaše si pamatuji jako velmi podnětného mentora, důsledného a přísného, ale také laskavého člověka, nadaného zvláštním smyslem pro humor. Jeho život provázela řada paradoxních okolností.

Narodil se roku 1933 v Těmicích na jižní Moravě v tradičně katolické rodině zedníka jako nejstarší z pěti dětí. Na jezuitské gymnázium na Velehradě nastoupil na samotném konci druhé světové války v roce 1945. Po únoru 1948, s nástupem komunistů k moci, se církevní instituce včetně škol staly terčem perzekuce. Gymnázium na Velehradě a jezuitský seminář byly komunisty obsazeny na jaře 1950 v rámci Akce K. Tehdy sedmnáctiletý Kolmaš byl spolu se svými spolužáky a novici semináře téměř půl roku internován v severočeském Bohosudově. Později na tyto události vzpomínal pro Pamět národa: „Profesory uvěznili a s novici nevěděla strana a vláda, jak naložit. Nakonec nás novice až do září drželi v internaci." Klášter v Bohosudově byl tehdy prakticky proměněn v tábor střežený Státní bezpečností. Každý den, nastoupení na dvoře, museli internovaní novicové poslouchat propagandistické proslovy. Společně s ostatními internovanými byl Kolmaš přinucen zlikvidovat místní knihovnu. Po celou

* Text je upraveným českým překladem původního anglického textu, který byl publikován na stránkách Mezinárodní asociace pro tibetská studia - viz Daniel Berounský, „Josef Kolmaš (1933-2021)“ [online], <https://www.iats.info/2021/03/josef -kolmas-1933-2021/>, 3. 3. 2021 [10. 4. 2021].

1 Andrea Jelínková, „Prof. PhDr., DrSc. Josef Kolmaš (*1933-†2021): První český tibetolog“ [online], in: Pamět národa, <https://www.pametnaroda.cz/cs/kolmas-josef -20140515-0>, [10. 4. 2021]. 
dobu nesměl přijímat návštěvy a na vycházkách jej doprovázel dozorce. Po dobu prvních tř́i měsíců pobytu ani nemohl informovat své rodiče o tom, že je naživu.

Později byl přidělen na stavebnické práce na přehradě Klíčava u Kladna, jak vzpomíná: „Když jsme byli na Klíčavě, budovali jsme hráz a cesty kolem přehrady. Přivezli nám tam nějaké svazačky, které nás měly rozptylovat, chtěly se s námi družit a tančit. Snažili se nás evidentně převychovat.“2 Posléze byl Kolmaš převezen do zrušeného františkánského kláštera v Hájku u Prahy, odkud byl pak propuštěn.

Vrátil se ke studiu na kyjovském gymnáziu, kde jej učitel Ladislav Dlouhý podporoval v zájmu o orientální jazyky. Díky němu se Kolmaš také seznámil s časopisem Nový Orient, ve kterém vycházela učebnice čínštiny na pokračování.

Po maturitě v roce 1952 byl přijat ke studiu češtiny a ruštiny na univerzitě v Olomouci, což byla jedna ze dvou možností, kterou absolventi kyjovského gymnázia v časech státního plánování dostali. On však byl odhodlaný studovat čínštinu, což bylo možné pouze na Karlově univerzitě v Praze. Po maturitě proto osobně navštívil ministra školství Ladislava Štolla, bigotního stalinistu, a kupodivu se mu podařilo jej přesvědčit, aby mu udělil svolení.

V letech 1952-1957 studoval čínštinu a také tibetštinu a tocharštinu pod vedením Pavla Pouchy (1905-1986). Jak takové studium probíhalo, mi Josef Kolmaš po letech vyličil: „Na první hodině mi Poucha vysvětlil tibetské písmo a jeho užití. Na další lekci přinesl tibetský překlad Nového zákona a dal mi jej se slovy: ,České znění máš, tak se snaž.““

Po skončení studií v roce 1957 Kolmaš získal postgraduální stipendium na Ústředním národnostním institutu v Pekingu, kde strávil dva roky. Tento pobyt se stal klíčovým pro jeho budoucí výzkum na poli tibetanistiky. Na tomto institutu byl prvním zahraničním studentem, pro něj samotného to byla první zahraniční cesta. Období jeho pobytu v Cíně však bylo provázeno bouřlivým vývojem v zemi. V letech 1958-1960 probíhala kampaň „Velký skok vpřed“, následovaná hladomorem v letech 1958-1962, který si vyžádal 35-45 milionů obětí. Některé scény ilustrující dobovou situaci v Číně Kolmaš později vylíčil. Například byl svědkem situace, kdy vedoucí ústavu chytal mouchy do malého papírového pytlíku v rámci „Kampaně proti čtyřem škůdcům“" která usilovala o vyhubení krys, much, komárů a vrabců. Nesmírný stud Kolmaš pocítil, když jej vedoucí ústavu požádal o kousek cukru pro své děti, které cukr nikdy neviděly. Sám totiž dostával proviant na sovětské ambasádě, což mu každodenní život v Pekingu značně usnadnilo.

2 Ibid. 
Během pobytu v Pekingu trávil později čas na Ústředním národnostním institutu s dalším cizincem, Jurijem Parfionovičem (1921-1990), autorem tibetsko-ruského slovníku. Parfionovič byl členem moskevského Orientálního ústavu Akademie věd, ale před akademickou kariérou byl vojákem Rudé armády, účastnil se sovětsko-finské války, byl členem špionážního oddílu. Účastnil se dobytí Berlína a konec druhé světové války slavil v Praze. Kolmaš si ho pamatoval jako př́jemného společníka, ale i jako člověka, který hodně pil. Pronásledovaly ho noční můry z jeho válečné minulosti, zejména moment, kdy byl donucen zastřelit své blízké kamarády.

Na své učitele v Pekingu Kolmaš vždy vzpomínal s vděčností. Jedním z nich byl Ngawang Döndub (1931-2017), o kterém poté, co opustil Peking, neměl žádné zprávy. Až v roce 1969 během audience u 14. dalajlamy v indické Dharamsale zmínil jeho jméno. Dalajlama pokynul svému tajemníkovi a po chvíli se Ngawang Döndub objevil přímo před překvapeným a dojatým Kolmašem.

Kolmašovým hlavním učitelem tibetštiny byl však čínský vědec Yu Daoquan (1901-1999), který od roku 1934 studoval v Paříži a od roku 1938 vyučoval v Londýně na Škole orientálních a afrických studií (SOAS). Kolmaš často hovořil o jeho nesobeckosti a vzpomínal na něj jako na „,skutečného bódhisattvu“. Yu Daoquan měl dobré konexe s Tibetany v Derge, díky čemuž mohl Kolmaš během svého pobytu objednat kompletní vydání tibetského kánonu Kandžuru, který posléze poslal do Orientálního ústavu v Praze.

Za pobytu v Pekingu také Kolmaš pořídil rukopisnou kopii tibetské kroniky ze 14. století, kterou mnohem později, v roce 1998, publikoval v komentovaném českém překladu pod názvem Zrcadlo králů: Tibetská kronika 14. století (Praha: Vyšehrad 1998). Tato publikace představuje naplnění jednoho z badatelských snů, který měl již od počátků své vědecké kariéry.

Kolmaš také plánoval navštívit Derge, centrum drobného království S věhlasnou tiskárnou. Na cestu se však vydal až v bouřlivém roce 1959: „Dojel jsem do Lan-čou v provincii Kan-su a už jsem viděl proudy vagonů s tanky a děly, které směřovaly do Tibetu. “3 Po útěku dalajlamy do Indie ve Lhase propuklo povstání; v Lan-čou pak Kolmaše dostihl telegram, který mu nařizoval okamžitý návrat do Pekingu.

Po návratu do Československa v roce 1959 pracoval v Orientálním ústavu Akademie věd, kde zúročil vše, co načerpal během pobytu v Číně. Po jistém uvolnění režimu v 60. letech, kdy mohl navštívit jako hostující profesor Australskou národní univerzitu v Canbeře (1966), však nastalo

3 Ibid. 
období normalizace. Musel překládat politické dokumenty z čínštiny, navzdory tomu pokračoval ve vědecké práci. V letech 1969 a 1978 navštívil Indii, v roce 1979 se v Oxfordu stal jedním ze zakládajících členů Mezinárodní asociace pro tibetská studia (IATS).

Po sametové revoluci došlo $\mathrm{k}$ mnohým změnám i v samotném Orientálním ústavu. V letech 1994-2002 zde Kolmaš působil jako ředitel, v následujícím roce odešel do důchodu. Josef Kolmaš spolu se svou manželkou Marií, která zemřela v roce 2006, vychoval syna Vladimíra a dceru Ivanu, poslední léta života pobýval s ohledem na vážné onemocnění v domě s pečovatelskou službou.

Pro dílo Josefa Kolmaše je příznačné využití znalostí jak čínštiny, tak tibetštiny. Mezi jeho mezinárodně oceňované práce patří studie věnované čínsko-tibetským vztahům: Tibet and Imperial China (Canberra: Australian National University, Centre of Oriental Studies 1967), The Ambans and Assistant Ambans of Tibet: A Chronological Study (Prague: The Oriental Insititute of the Academy of Sciences 1994), „Four Letters of Po Chü-i to the Tibetan Authorities (808-810 A.D.)“" (Archiv Orientální 34, 1966, 375-410) a „Ch'ing shih kao on Modern History of Tibet (19031912)“ (Archiv Orientální 32, 1964, 77-99).

Právě Kolmaš začal jako jeden z prvních využívat čínské prameny pro bádání o tibetských dějinách. Českému čtenáři budou dobře známy jeho překlady z tibetštiny Nangsa Öbum (Praha: Unitaria 1993), Zrcadlo králi̊: Tibetská kronika 14. století (Praha: Vyšehrad 1998) a Gurbum aneb Sto tisíc písní jógina Milaräpy (Praha: Academia 2009). Z čínštiny do češtiny přeložil cestopisy buddhistických poutníkủ Fa-siena (Zápisky o buddhistických zemích, Praha: Odeon 1972) a Süan-canga (Zápisky o západních krajinách za Velkých Tchangů, Praha: Academia 2002). Z dalších jeho překladů lze uvést také latinské dopisy českého jezuitského misionáře Karla Slavíčka z Číny (Listy z Číny do vlasti a jiná korespondence s evropskými hvězdáři [1716-1735], Praha: Vyšehrad 1995). Z ruštiny přeložil cestopis Gombodžaba Cybikova (Cesta $k$ posvátným místům Tibetu, Praha: Vyšehrad 1987).

Na dveřích své pracovny míval Kolmaš citát připisovaný sv. Benediktu: „Serva ordinem et ordo servabit te“, „Zachovávej pořádek a pořádek zachová tebe“. Jeho životní cesta $\mathrm{v}$ bouřlivých obdobích dějin a výsledky práce, kterou po sobě zanechal, dobře ukazují, s jakou vážností toto pravidlo uplatňoval. 